\title{
Insight and recovery and the stigma of mental illness - analysis of the phenomenon of insight in schizophrenia and its correlations with the processes of stigma and self-stigma
}

\author{
Wgląd i zdrowienie a piętno choroby psychicznej - analiza zjawiska wglądu w schizofrenii \\ i jego relacji z procesami stygmatyzacji i autostygmatyzacji
Ewelina Soroka ${ }^{1}$ ABDEF, Kamila Dziwota ${ }^{2}$ ABDEF, Justyna Pawęzka ${ }^{1}{ }_{\mathrm{BE}}$, Marcin Olajossy ${ }^{1} \mathrm{DE}$ \\ ${ }^{1}$ II Department of Psychiatry and Psychiatric Rehabilitation in Lublin, Medical University of Lublin
2 Department of Psychotherapy Jagiellonian University - Colegium Medicum, Cracow
}

\begin{abstract}
Does better insight associated with the process of recovery mean a stronger sense of mental illness stigma? This article presents the relationship between a multidimensional construct, which is the insight and the phenomena of stigma and self-stigma of patients diagnosed with schizophrenia. It is well known that the term insight contains: a sense of illness, the patient's attitude to its symptoms, explanation of the causes of the illness, attitude to the rationale of treatment and awareness of the risk of relapse.On the other hand, self-stigma occurs when the patient internalizes and refers to himself/herselfnegative and stigmatizing social attitudes, conditioned by the presence of conventionalbeliefs, strengthened by the media, and this weakens the process of recovery.

How much does good insight strengthen the patient on the way to fuller social functioning, and how much does it imprint stigma of mental illness and weaken its positionin society? The authors of the paper are discussing the subject of insight and stigma from the patient's perspective, over the patient's attitude towards the diagnosis of schizophrenia, the process of recovery and the aspect of hope important in recovery.These study of construct insight shows that the relationship insight-recovery-stigma is a multi-dimensional plane, dependent on various factors, that needs constant deepening and complementing with further research.
\end{abstract}

Keywords: insight, stigma, schizo phrenia, recovery

\section{Streszczenie}

Czy lepszy wgląd związany z procesem zdrowienia oznacza silniejsze poczucie piętna choroby psychicznej? Niniejszy artykuł ukazuje relację pomiędzy wielowymiarowym konstruktem, jakim jest wgląd oraz zjawiskami stygmatyzacji i autostygmatyzacji pacjentów z rozpoznaniem schizofrenii. Powszechnie wiadomo, iż termin wgląd zawiera w sobie: poczucie choroby, stosunek pacjenta do jej objawów, wyjaśnienie przyczyn choroby, stosunek do zasadności leczenia oraz świadomość ryzyka nawrotów. Zaś autostygmatyzacja ma miejsce wówczas, gdy pacjent internalizuje i odnosi do siebie negatywne i piętnujące postawy społeczne, uwarunkowane obecnością stereotypowych, umacnianych przez media przekonań, a to utrudnia proces zdrowienia. Na ile dobry wglą d umacnia pacjenta $\mathrm{w}$ drodze ku pełniejszemu funkcjonowaniu społecznemu, a na ile odciska piętno choroby psychicznej i osłabia jego pozycję w społeczeństwie? Autorzy tej pracy pochylili się nad zagadnieniem wglądu i stygmatyzacji z perspektywy acjenta, nad jego postawą wobec diagnozy schizofrenii, procesem zdrowienia oraz aspektem nadziei, jakże ważnej w zdrowieniu. Owe studium konstruktu wglądu dowodzi, że relacja wgląd-zdrowienie-piętno jest płaszczyzną wielowymiarową, uzależnioną od różnych czynników, stale wymagającą pogłębienia i uzupełnienia dalszymi badaniami naukowymi.

Słowa kluczowe: wgląd, stygmatyzacja, schizofrenia, zdrowienie

\section{Introduction}

Does better insight associated with the process of recovery mean a stronger sense of mental illness stigma?

The aim of this article is to analyze the phenomenon of insight in the light of the latest scientific research and to show the relationship between the level of insight and recovery, social functioning, stigma and self-stigma and hope in relation to schizophrenia. The authors included available monographs on insight topics and the latest articles found in the Scopus databaseand using Google Scholar, entering the terms 'insight', 'recovery', 'stigma' and 'schizophrenia'.

\section{Insight}

Non- awareness of the disease - for years recognized as a common feature of schizophrenia, is associated with 
worse cooperation in treatment, social isolation, maladaptation, impaired psychosocial functioning, worse course of the disease due to the greater severity of psychopathological symptoms [1].

According to Greenfield et al., the concept of insight includes: the sense of illness, the patient's attitude to its symptoms, explanation of the causes, conditions of the disease, attitude to the rationale of treatment and awareness of the risk of relapse. [2].

The insight in mental disorders consists of at least three dimensions, i.e. the ability to distinguish that you are mentally ill, the possibility of recognizing extraordinary psychological experiences as pathological and adherence to treatment recommendations [30].

Nowadays it is known that insight is a multi-faceted phenomenon and it is difficult to determine how it relates to the specific dimensions of a schizophrenia-like disorder. The lack of consensus on the definition of insight suggests that in schizophrenia it is a complex phenomenon and cannot be assessed in a standardized way. Although the awareness of the disease seems to be an important problem in terms of patient care, no agreement has yet been reached on the possible positive or harmful effects of a good level of insight on the patients, on the course of their disorder and care of them.In order to understand the effects of insight, patients suffering from schizophrenia should be subjected to standardized interviews in different phases of remission, because it is important to confront the point of view on what insight means for the experts in the field of mental health as well as for patients themselves [3].

According to Beck, the above-mentioned definition of insight by Greenfield concerns only the so-called clinical insight. What is different, is the cognitive insight, which is understood as the patient's openness to feedback, and thus - the ability to correct irrelevant interpretations and distorted beliefs. This kind of insight requires the efficiency of higher metacognitive processes [4].

Poyraz, B. C.. et al., assess the correlations of clinical and cognitive insight in patients in the acute stage of psychosis and analyze acute treatment on these variables. Forty seven patients who were recently hospitalized for exacerbation of schizophrenia were examined. Positive and Negative Syndrome Scale (PANSS), Schedule for the Assessment of Insight-Expanded Version (SAI-E), Beck Cognitive Insight Scale (BCIS), and Neurocognitive Test Battery were used.Patients with schizophrenia gained clinical insight after treatment. Cognitive insight did not change significantly after the pharmacotherapy. Insight showed significant negative correlations with positive symptoms and general psychopathology, but not with negative symptoms. Clinical insight was not related to neuropsychological functioning in this group. Acquiring clinical insight in the acute phase of the disease was associated with the resolution of positive symptoms, but not with the change in neuropsychological functioning.Some significant correlations have been identified between clinical and cognitive insight, suggesting that cognitive insight promotes clinical insight, but this is not medically dependent. Conclusion from the research by Poyraz et al. is that long-term treatment may be necessary to understand the impact of insight on the results of the therapy process of patients with schizophrenia [5].

Lack of insight is a very common phenomenon in schizophrenic psychoses because, as research shows, about $97 \%$ of patients with the first episode of the disease do not associate their symptoms with the disease process [6].

What's more, patients with schizophrenia are characterized by a lower level of insight into the disease than patients with schizoaffective disorder and psychotic depression [7].

Despite a very low sense of insight into schizophrenia, there has been created a questionnaire for insight into schizophrenia - "My thoughts and feelings" - having a good reliability and fairly good validity, which can be used for screening purposes. What's more, it can also be useful in measuring the change in the sense of insight and in assessing the quality of insight through discussion on the answers given by the patient [8].

Next to the insight - the issue of the sense of influence that seems like a constructisworth considering.The studies of Gawęda et al.,showed a relationship between the sense of influence on the course of the disease and the level of insight in patients with schizophrenia. A moderate correlation shows that although two variables are related, they are not identical [9].

Ćurčić-Blake, B. et al. , assume that the disorder of insight into the disease is relatedwith worse treatment results, which is common in schizophrenia. The insight reported as the processes of self-reflexive processing is concentrated in the medial cortex.

Therefore, it was hypothesised that anatomical and functional pathways toand from the ventrally mediated prefrontal cortex (VmPFC) would differ in patientsdepending on the degree of disturbance of their insight. Forty-five patientswith schizophrenia and 19 healthy volunteers were subjected to self-reflection during fMRI neuroimaging and diffusion tensor imaging. Increased effective connectivity was observed from the posterior cingulate cortex(PCC), inferior parietal lobe (IPL), and dorsal mPFC (dmPFC) along the VmPFC with lower levels of insight and falling from vmPFC to IPL. Stronger communication from PCC to VmPFC during the task was associated with poorer insights [10].

\section{Recovery and stigma}

In the recovery process, it is important to engage the patient individually in regaining control over his/her life 
and opposing the stigma of mental illness. Empowerment, i.e. strengthening, means that in the face of illness, a mentally ill person can become a support for himself/herself. However, this is not a frequent phenomenon, because in reality patients often think about mental illnesses in a stereotypical usual way abused in society. It happens that even before they get ill, they grow up and educate in an environment that has a bad attitude towards the mentally ill.This is probably why, after becoming ill, they become subject to the process of self-stigmatization, which consists in internalizing and referring to negative social attitudes, which undoubtedly weakens the process of recovery $[11,12]$.

The reasons for the stigmatization of people with mental disorders, according to Marek Jarema, result from ignorance of the problems of mental disorders and from the beliefabout the threat that these people pose to others, which is unfortunately maintained by the media [13].

In chronically ill patients, there is often a lack of personal autonomy, falling out of social roles and a deficit of close and significant interpersonal relations. Such social functioning may be associated with the course of the disease, but on the other hand, it can be seen as the effect of stigma and discrimination experienced on a daily basis.Research indicates that a well-developed network of social connections is crucial for the well-being of patients. The obtained support leads to a better insight into the disease and results in a higher subjective satisfaction with life and treatment $[14,15]$.

A mentally ill person should (to the best of their abilities) take up the trouble of opposing stigma. Unfortunately, there is always the risk of taking the stigmatizing attitude of the environment onto oneself. Research shows that self-stigmatization is a significant hindrance in fulfilling social roles. The patients' closest are often their only and the key source of social support, on the other hand, they remain under the devastating influence of the so-called courtesy stigma. The family, left to some extent alone, is often unable to be a sufficient support for the patient, as it requires support as the system as a whole [16].

Despite the previously mentioned positive correlates of insight, there are also negative links. Part of the research proves that in patients with better insight into the disease there is a higher risk of depression and suicidal tendencies than in patients with worse insight $[17,18]$.

Krupchanka et al.,in the pilot study emphasize the role of insight in moderating the relationship between depressive symptoms in patients with schizophrenia and stigmatization among their closest relatives. There is a positive correlation between insight and depressive symptoms in patients diagnosed with schizophrenia. Selfstigma - plays a mediating role here.Insight was examined as a potential moderator of the relationship between the occurrence of depressive symptoms in patients with schi- zophrenia and stigmatizing beliefs aimed at people diagnosed with mental illness in their social environment. From the initial sample of 120 pairs, data were collected from 96 patients diagnosed with paranoid schizophrenia and 96 of their close relatives (80\% response rate). The following tools were used in the study:"The Scale to Assessment of Unawareness of Mental Disorder," "Calgary Depression Scale for Schizophrenia" and "Brief Psychiatric Rating Scale." Stigmatizing views, attitudes towards close relatives of patients and people with mental disorders were assessed by the "Mental Health in Public Conscience Scale" .The severity of depressive symptoms among patients with schizophrenia was positively correlated with the intensity of stigmatizing beliefs of closest relatives. The dependence was moderated by the level of patients' awareness of the presence of symptoms of mental illness, depending on age, gender, duration of the disease, psychopathological symptoms [19].

Correlation of insight and depression and the fact that in most patients the lack of insight persists for a relatively long time could suggest a defensive role of insight [20].

In the work of A. Dequelsonet al., we find confirmation that clinical insight is a multidimensional concept with positive as well as negative consequences for patients with schizophrenia. Self-stigma seems to average the relationship between insight and depression. Patients in forensic psychiatry departments are particularly susceptible to the stigma associated with mental disorders, but also to criminal history. [21].

The authors indicate that the possibility of building a therapeutic relationshipin the treatment of schizophrenia facilitates better functioning, more effective reduction of psychotic symptoms and fulfillment of patients' personal goals. It was examined whether patients systematically cooperating with psychiatrists and more meticulously observing medical recommendations could function socially and clinically better and more efficiently compared to non-cooperating patients. The study included 300 patients suffering from schizophrenia. The patients were divided into two groups: an experimental group - patients systematically cooperating with doctors, a control group patients refusing to cooperate.Compared to noncooperating patients, patients systematically cooperating with their psychiatrists were more satisfied with the treatment effects and had a broader knowledge on the subject, which translated into better social functioning, more frequent professional activity and a positive assessment of their lives. The results indicate that systematic cooperation with the doctor results in better functioning of patients with schizophrenia [22].

The aim of the work entitled "Insight and recovery in schizophrenic patients" was to examine the correlation between insight and recovery in patients with schizophrenia 
according to the criteria of both symptomatic and functional remission. Seventy patients with paranoid schizophrenia were recruited and treated with olanzapine, risperidone,aripiprazole, haloperidol and ziprasidone.Visits were scheduled at the beginning of the study, after 12 and 36 months. There following scales were used: PANSS, GAF (Global Assessment of Functioning), SF-36 (Short Form 36 Health Survey), PGWBI and NOK. After 1 year, $50 \%$ of respondents obtained remission of symptoms, and $25.5 \%$ had adequate social functioning for 2 years or longer. Only $12 \%$ of respondents met all the criteria for remission for 2 years or longer.In the study group, an improvement in the level of insight was also found, especially in patients treated with second generation antipsychotics (SGA). The recovery of insight was positively correlated with female sex, older age, SGA treatment, predisease social adaptation and low level of negative symptoms of schizophrenia at the beginning of the study [23].

With the increase in the level of insight into the disease, the sense of influence on its course increases, and thus the level of social functioning in all aspects of a patient's life increases. Patients are aware of the need to take and comply with the principles of treatment, selfobservation, demonstrate the ability to establish and maintain long-term interpersonal relationships and independence in satisfying basic life needs, resulting in longer remission periods, and the patients have a sense of freedomfrom the disease and are better functioning in the environment, that is not always fully aware of their needs, $[9,24]$.

Wilczek-Rużyczka et al.,assessed the relationship between the level of insight and the sense of influence on the course of the disease and the level of social functioning of patients with schizophrenia. The study group comprised 152 patients diagnosed with schizophrenia, 91 women (59.9\%) and 61 men (40.1\%). Patients were hospitalized in the St. Jadwiga Provincial Specialist Neuropsychiatric Complex in Opole and at the Józef Babinski Specialist Hospital of theIndependent Public Health Care Unit in Krakow.The methods of the diagnostic survey and the technique of the questionnaire were used for the research. Three standardized questionnaires were used the Questionnaire of Insight into the Schizophrenia "My Thoughts and Feelings", " Short Scale of The Sense of Influence for the Course of Disease - A Version for Schizophrenia and the Social Functioning Scale" developed by Max Birchwood. The results showed that the level of insight into the disease and the sense of influence on its course in patients with schizophrenia were mediocre.On the other hand, the level of social functioning in individual factors varied. The highest results concern the area of recovering from isolation, communication and ties with others, as well as possible (potential) independence. The respondents obtained average results in the field of recreation and entertainment as well as independence. A low level was found in terms of social contacts and employment. In addition, a positive correlation was found between the level of insight and the sense of influence on the course of the disease.This, in turn, determines the improvement in social functioning in all its ranges. Patients with higher insights function higher in the area of recovering from isolation and organization of free time (through entertainment and recreation). Patients with a higher sense of influence on the course of the disease have better motivation to work, better communication skills and building relationships with others, moreover, they are characterized by greater independence of basic life needs and higher self-reliance [25].

Undoubtedly, psychosocial skills training is important in the process of recovering and recovering insight. The authors of the work "Effect of Psychosocial Skills Training on Disease Symptoms, Insight, Internalized Stigmatization, and Social Functioning in Patients with Schizophrenia" emphasize the impact of psychosocial skills training on reduction of schizophrenia symptoms, insight, internalization of stigmatization and social functioning of patients diagnosed with schizophrenia. The study was conducted to determine the impact of Psychosocial Skills Training (Psst) on the symptoms of the disease, insight, internalization of stigma and social functioning in patients with schizophrenia.The study involved 25 outpatients diagnosed with paranoid schizophrenia. The program had significant results in patients with schizophrenia to improve the severity of symptoms, increase activity and overcome the feeling of stigma with mental illness [26].

It is worth noting here that some therapeutic interventions tend to increase insight, and in people with psychotic symptoms it is risky. As the research by HassonOhayon et al. shows, insight may in certain situations worsen the quality of life, because it negatively correlates with the hope for success. However, if a person can perceive disease symptoms and differentiate them with symptoms of health, hope, allows them to use insight as a tool useful in overcoming limitations conditioned by illness $[27,28]$.

At the end, it is worth quoting - "Discriminated social group is in some way the same as the general public, and in some part different." The question is: is there a clear boundary? If the term "person suffering from schizophrenia", has already been used, is schizophrenia like abackpack that can be removed or a hump that distorts a figure? It seems that people suffering from schizophrenia, included in the destigmatization transmission (meaning those with better remissions and usually having what psychiatrists call "insight") in the therapeutic process are actually benefiting better of being treated than "people with schizophrenia," seeking a way to return to normality "[29].

\section{Conclusion}

This review of the research illustrates how a multidimensional and complex construct is theinsight, which 
should be distinguished from the sense of illness and the notion of criticism, distinguished between what clinical insight means and what cognitive insightincludes.

Currently, some important correlations are known between clinical and cognitive insight, suggesting that cognitive insight supports clinical insight, which is not dependent on the treatment process.

The phenomenon of insight has a positive effect on the patients, when they have a developed social support network, gain greater satisfaction with life, on the other hand, insight reflecting the sense of illness negatively correlates with the hope for success and improvement of the quality of life and sometimes makes the patients become isolated, adopt stereotypical beliefs about mental illness and internalize the stigma of schizophrenia, which has negative consequences for the processes of empowerment and recovery.

Description of the relationship between the phenomena: insight-recovery-stigma certainly needs to be supplemented by further research.

\section{Wprowadzenie}

Czy lepszy wgląd związany z procesem zdrowienia oznacza silniejsze poczucie piętna choroby psychicznej?

Celem niniejszego artykułu jest analiza zjawiska wglądu w świetle najnowszych badań naukowych oraz ukazanie związku pomiędzy poziomem wglądu a zdrowieniem, funkcjonowaniem społecznym, stygmatyzacją i autostygmatyzacją oraz nadzieją w odniesieniu do schizofrenii. Autorzy uwzględnili dostępne piśmiennictwo poświęcone zagadnieniu wglądu oraz wybrane prace naukowe wyszukane w bazie Scopus i za pomocą wyszukiwarki Google Scholar, wpisując hasła: 'insight', 'recovery', 'stigma'i 'schizophrenia'.

\section{Wgląd w schizofrenii}

Nieświadomość choroby - od lat uznawana za powszechną cechę schizofrenii, wiąże się $\mathrm{z}$ gorszą współpracą w leczeniu, izolacją społeczną, nieprzystosowaniem, zaburzonym funkcjonowaniem psychospołecznym, gorszym przebiegiem choroby z uwagi na większe nasilenie objawów psychopatologicznych [1]. Zdaniem Greenfielda i wsp. pojęcie wglądu zawiera w sobie: poczucie choroby, stosunek pacjenta do jej objawów, wyjaśnienie przyczyn, uwarunkowań choroby, stosunek do zasadności leczenia oraz świadomość ryzyka nawrotów. [2].Współcześnie wiadomo, że wgląd jest zjawiskiem wieloaspektowym i trudno jest ustalić jak odnosi się ono do konkretnych wymiarów zaburzenia typu schizofrenii. Brak konsensusu w sprawie definicji wglądu sugeruje, że w schizofrenii jest on zjawiskiem złożonym i nie da się ocenić go w znormalizowany sposób. Chociaż świadomość choroby wydaje się być ważnym problemem w kwestii opieki nad pacjentem, nie osiągnięto jeszcze porozumienia w sprawie możliwych skutków pozytywnych lub szkodliwych dobrego poziomu wglądu na pacjenta, na przebieg jego zaburzenia i sprawowaną nad nim opiekę. Aby zrozumieć skutki wglądu należałoby pacjentów cierpiących na schizofrenię, w różnych fazach remisji, poddać wystandaryzowanym wywiadom, ważna jest bowiem konfrontacja punktu widzenia na temat tego, co wgląd oznacza dla ekspertów w dziedzinie ochrony zdrowia psychicznego jak i dla samych pacjentów [3] Przytoczona powyżej, definicja wglądu autorstwa Greenfielda dotyczy wyłącznie tzw. wglądu klinicznego. Czym innym natomiast jest wgląd poznawczy, który rozumie się jako otwartość pacjenta na informacje zwrotne, a co za tym idzie - umiejętność dokonania korekty nietrafnych interpretacji i zniekształconych przekonań. Ten rodzaj wglądu wymaga sprawności wyższych procesów metapoznawczych [4,5].

Brak wglądu jest bardzo powszechnym zjawiskiem w psychozach schizofrenicznych, gdyż, jak pokazują badania, około 97\% pacjentów z pierwszym epizodem choroby nie wiąże swoich objawów z procesem chorobowym [6]. Co więcej, pacjenci z rozpoznaniem schizofrenii charakteryzują się niższym poziomem wglądu w chorobę niż pacjenci z zaburzeniem schizoafektywnym oraz depresją psychotyczną [7]. Celem oceny wglądu w schizofrenii stworzono „Moje myśli i odczucia” - mający dobrą rzetelność i zadowalającą trafność, który może stosowany do badań przesiewowych [8].

Warto rozważyć jeszcze obok wglądu - zagadnienie poczucia wpływu, które wydaje się podobnym konstruktem. W badaniach Gawędy i wsp. wykazano związek poczucia wpływu na przebieg choroby z poziomem wglądu u pacjentów chorych na schizofrenię. Umiarkowana korelacja pokazuje, że mimo iż dwie zmienne są ze sobą związane, nie są tożsame [9]. Ćurčić-Blake, B. i wsp. zakładają, że zaburzenia wglądu w chorobę wiążą się z gorszymi wynikami leczenia, co jest powszechne w schizofrenii [10].

\section{Zdrowienie i stygma}

W procesie zdrowienia (ang. recovery) ważne jest indywidualne zaangażowanie chorego w odzyskiwaniu kontroli nad swoim życiem i przeciwstawienie się stygmatowi choroby psychicznej. Empowerment tj. umacnianie oznacza, że w obliczu choroby chory psychicznie może sam stać się dla siebie oparciem. Aczkolwiek nie jest to zjawisko częste, gdyż w rzeczywistości pacjenci często myślą o chorobach psychicznych w sposób utarty w społeczeństwie, 
stereotypowy. Zdarza się, że jeszcze przed zachorowaniem wzrastają i wychowują się $\mathrm{w}$ otoczeniu, mającym zły stosunek do chorych psychicznie. Prawdopodobnie dlatego tak łatwo po zachorowaniu ulegają procesowi autostygmatyzacji, który polega na internalizowaniu oraz odnoszeniu do siebie negatywnych postaw społecznych, co niewątpliwie osłabia proces zdrowienia [11,12,13]. U przewlekle chorych często obserwuje się brak autonomii osobistej, wypadanie $\mathrm{z}$ ról społecznych oraz deficyt bliskich i znaczących relacji interpersonalnych. Takie funkcjonowanie społeczne może być związane $\mathrm{z}$ przebiegiem choroby, ale $\mathrm{z}$ drugiej strony można to rozpatrywać jako efekt doświadczanej na co dzień stygmatyzacji i dyskryminacji. Badania wskazują, że rozwinięta sieć społecznych powiązań jest kluczowa dla dobrego funkcjonowania chorych. Otrzymywane oparcie prowadzi do lepszego wglądu w chorobę oraz skutkuje wyższą subiektywną satysfakcją z życia i z leczenia [14,15].

Osoba chora psychicznie powinna (na miarę swoich możliwości) podejmować trud przeciwstawienia się stygmatowi. Niestety zawsze istnieje ryzyko przejęcia piętnującej postawy otoczenia na samego siebie. Badania podają, że autostygmatyzacja jest istotnym utrudnieniem w pełnieniu ról społecznych. Najbliżsi pacjenta są często jego jedynym i kluczowym źródłem wsparcia społecznego, z drugiej strony sami pozostają pod niszczącym wpływem tzw. piętna udzielonego (ang. courtesy stigma). Rodzina pozostawiona niejako sama sobie, często nie jest w stanie być wystarczającym oparciem dla chorego, gdyż wymaga wsparcia jako całość systemu[16].

Mimo wymienionych wcześniej pozytywnych korelatów wglądu, istnieją także negatywne powiązania. Otóż część badań dowodzi, że u pacjentów z lepszym wglądem w chorobę obserwuje się wyższe ryzyko objawów depresyjnych oraz tendencji samobójczych niż u pacjentów z gorszym wglądem $[17,18]$. Istnieje zatem pozytywna zależność pomiędzy wglądem a objawami depresyjnymi u pacjentów ze zdiagnozowaną schizofrenią. Autostygmatyzacja - self stigma - odgrywa tu rolę pośredniczącą. Zbadano wgląd jako potencjalny moderator zależności pomiędzy występowaniem objawów depresyjnych u pacjentów ze schizofrenią a piętnującymi przekonaniami wymierzonymi w ludzi $\mathrm{z}$ diagnozą choroby psychicznej $\mathrm{w}$ ich środowisku społecznym. Z początkowej próby 120 par dane zostały zebrane od 96 pacjentów $\mathrm{z}$ diagnozą schizofrenii paranoidalnej oraz 96 ich najbliższych krewnych $(80 \%$ odsetek odpowiedzi). W badaniu stosowano następujące narzędzia: "The Scale to Assess Unawareness of Mental Disorder," "Calgary Depression Scale for Schizophrenia" oraz "Brief Psychiatric Rating Scale." Stygmatyzujące poglądy, postawy wobec najbliższych krewnych pacjentów i wobec ludzi $\mathrm{z}$ zaburzeniami psychicznymi oceniono dzięki "Mental Health in Public Conscience" Scale. Nasilenie objawów depresyjnych wśród pacjentów ze schizofrenią było pozytywnie skorelowane z intensywnością piętnujących wierzeń najbliższych krewnych. Zależność była moderowana przez poziom świadomości pacjentów obecności objawów choroby psychicznej, uzależnionej od wieku, płci, czasu trwania choroby, objawów psychopatologicznych [19].

W pracy A. Dequelsona i wsp. znajdujemy potwierdzenie faktu, że wgląd kliniczny jest pojęciem wielowymiarowym $\mathrm{z}$ pozytywnymi jak i negatywnymi konsekwencjami dla pacjentów ze schizofrenią, zaś sama autostygmatyzacja wydaje się uśredniać relację między wglądem i depresją. Pacjenci z oddziałów psychiatrii sądowej są szczególnie podatni na piętno związane z zaburzeniami psychicznymi, ale również historią przestępczą. [20, 21].

Wydaje się, że możliwość budowania relacji terapeutycznej w leczeniu schizofrenii ułatwia lepsze funkcjonowanie, bardziej skuteczną redukcję objawów psychotycznych i spełnienie osobistych celów pacjentów. Wyniki wskazują, że systematyczna współpraca z lekarzem powoduje szybsze zdrowienie przekładające się na lepsze funkcjonowanie chorych na schizofrenię [22].

Celem pracy pt. "Insight and recovery in schizophrenic patients" było zbadanie korelacji między wglądem i zdrowieniem u pacjentów ze schizofrenią według kryteriów zarówno objawowej jak i funkcjonalnej remisji. Odzyskiwanie wglądu było pozytywnie skorelowane z płcią żeńską, starszym wiekiem, leczeniem, wstępnie chorobową adaptacją społeczną i niskim poziomem negatywnych objawów schizofrenii na początku badania [23].

Wraz ze wzrostem poziomu wglądu w chorobę wzrasta poczucie wpływu na jej przebieg, a tym samym zwiększa się poziom funkcjonowania społecznego we wszystkich aspektach życia chorego. Pacjenci mają świadomość konieczności podjęcia i przestrzegania zasad leczenia, samoobserwacji, wykazują się umiejętnością nawiązywania i podtrzymywania trwałych relacji interpersonalnych oraz samodzielności w zaspokajaniu podstawowych potrzeb życiowych, w wyniku czego wydłużają się okresy remisji, a chorzy lepiej funkcjonują w środowisku i mają poczucie wolności od choroby [9,24].

Wilczek-Rużyczka i wsp. w swoich badaniach ocenili związek pomiędzy poziomem wglądu i poczuciem wpływu na przebieg choroby a poziomem społecznego funkcjonowania pacjentów ze schizofrenią. Wyniki wykazały, że poziom wglądu w chorobę oraz poczucie wpływu na jej przebieg u pacjentów ze schizofrenią są przeciętne. Natomiast poziom funkcjonowania społecznego w poszczególnych czynnikach bywa różny. Najwyższe wyniki dotyczą obszaru wychodzenia z izolacji, 
komunikacji i więzi z innymi, a także samodzielności możliwej (potencjalnej). Badani uzyskali przeciętne wyniki w zakresie rekreacji i rozrywki oraz samodzielności realizowanej. Niski poziom stwierdzono $\mathrm{w}$ zakresie kontaktów społecznych oraz zatrudnienia. Dodatkowo, wykazano korelację pozytywną między poziomem wglądu a poczuciem wpływu na przebieg choroby. To z kolei, determinuje polepszenie funkcjonowania społecznego we wszystkich jego zakresach. Pacjenci $\mathrm{z}$ wyższym wglądem funkcjonują wyżej w obszarze wychodzenia $\mathrm{z}$ izolacji i organizacji czasu wolnego. Pacjenci z wyższym poczuciem wpływu na przebieg choroby mają lepszą motywację do pracy, lepsze umiejętności komunikacji i budowania więzi z innymi, a ponadto charakteryzuje ich większa samodzielność zaspokojenia podstawowych potrzeb życiowych i wyższa samodzielność możliwa [25].

Niewątpliwie w procesie zdrowienia i odzyskiwania wglądu ważny jest trening umiejętności psychospołecznych. Autorzy podkreślają wpływ treningu umiejętności psychospołecznych na redukcję objawów schizofrenii, wgląd, internalizowanie stygmatyzacji i funkcjonowanie społeczne pacjentów z rozpoznaniem schizofrenii. W jednym badaniu poddano 25 pacjentów ambulatoryjnych, u których postawiono diagnozę schizofrenii paranoidalnej. Program miał znaczące rezultaty u pacjentów ze schizofrenią w zakresie poprawy ciężkości objawów, zwiększenia aktywności i w pokonywaniu poczucia napiętnowania chorobą psychiczną [26].

Warto w tym miejscu zauważyć, że niektóre interwencje terapeutyczne zmierzają do zwiększenia wglądu, a u osób z objawami psychozy jest to ryzykowne. Jak pokazują badania Hasson-Ohayon i wsp. wgląd może w pewnych sytuacjach pogorszyć jakość życia, ponieważ negatywnie koreluje z nadzieją na sukces. Jeżeli jednak człowiek potrafi dostrzegać objawy chorobowe i różnicować je z przejawami zdrowia, nadzieja pozwala używać wglądu jako narzędzia użytecznego $\mathrm{w}$ pokonywaniu ograniczeń uwarunkowanych chorobą [27, 28].

Na zakończenie myślę, że warto przytoczyć cytat „Wydaje się, że osoby chorujące na schizofrenię, ujęte $w$ przekazie destygmatyzacyjnym (czyli te z lepszymi remisjami i zwykle mające to, co psychiatry określaja mianem "wgląu"), w procesie terapeutycznym rzeczywiście lepiej korzystaja z bycia traktowanymi niż "osoby ze schizofreniq", poszukujące drogi powrotu do normalności" [29].

\section{Podsumowanie}

Niniejszy przegląd badań oraz rozważania prowadzą do konkluzji o pozytywnym wpływie wglądu u pacjenta, który posiada prawidłowo rozwiniętą sieć społeczną, sieć oparcia, dzięki czemu zyskuje on większą satysfakcję z życia.
Z drugiej strony wgląd rozumiany jako odzwierciedlenie poczucia choroby psychicznej negatywnie koreluje $\mathrm{z}$ nadzieją na sukces i poprawę jakości życia oraz powoduje, że pacjent zaczyna się izolować, przyjmować stereotypowe przekonania na temat swojej choroby, choroby psychicznej a tym samym internalizować piętno schizofrenii. Ma to dalej negatywne konsekwencje dla procesów umacniania (empowerment) i samego zdrowienia (recovery).

Jakkolwiek, przy całej złożoności konstruktu wglądu i rozpiętości problematyki rehabilitacji psychiatrycznej pacjenta ze schizofrenią, wzajemne relacje zagadnień wgląd-zdrowienie-piętno zdają się stanowić intrygującą płaszczyznę badawczą, wartą uzupełnienia i pogłębienia w przyszłości.

\section{Conflict of interest}

The authors have declared no conflict of interest.

\section{References:}

1. Kępiński A.: Schizofrenia. Wydawnictwo Literackie, Kraków 2001.

2. Greenfield D., Strauss J.S., Bowers M.B., i in. Insight and interpretation of illness in recovery from psychosis. Schizophr. Bull. 1989; 15: 245-252.

3. Bouroubi, W., Banovic I., Andronikof A., Omnès C. Insight et schizophrénie: revue de la littérature. L'Évolution Psychiatrique,. 2016, 81(2), 405-422.

4. Beck A.T., Baruch E., Balter J.M., Steer R.A., Warman D.M.. A new instrument for measuring insight: the Beck Cognitive Insight Scale. Schizophr. Res. 2004; 68: 319-329.

5. Poyraz B. C.., Arikan M. K., Poyraz C. A., Turan Ş., Kani, A. S. Aydin, E. et al. Clinical and cognitive insight in patients with acute-phase psychosis: Association with treatment and neuropsychological functioning. Nordic journal of psychiatry, 2016, 1-8.

6. Dębowska G., Grzywa A., Karakuła H., Urbańska A. Poziom wglądu a czas trwania choroby, liczba hospitalizacji i nasilenie objawów psychopatologii w schizofrenii paranoidalnej. Badania nad Schizofrenią 1998; 99-112.

7. Pini S., Cassano G.B., Dell'osso L., Amador X.F. Insight into illness in schizophrenia, schizoaffective disorder, and mood dis-orders with psychotic features. Am. J. Psychiatry 2001; 158: 122-125.

8. Kokoszka, A., Telichowska-Leśna, A., Radzio R. Kwestionariusz wglądu w schizofrenię-„Moje myśli i odczucia”. Psychiatr. Pol, 2008, 42, 491-502.

9. Gawęda Ł., Buciński P., Staniszewski K. i wsp.: Związki wglądu w chorobę, poczucia wpływu na jej przebieg, stylów radzenia sobie z chorobą z objawami psychopatologicznymi w schizofre- nii. Psychiatria 2008; 5: 124-133.

10. Ćurčić-Blake B., van der Meer L., Pijnenborg G. H., David A. S., Aleman A. Insight and psychosis: Functional and anatomical brain connectivity and self-reflection in Schizophrenia. Human brain mapping, 2015, 36(12), 4859-4868.

11. Anczewska M, Wciórka J. Umacnianie - nadzieja czy uprzedzenia. Warszawa: Instytut Psychiatrii i Neurologii; 2007.

12. Corrigan P.W., Watson A.C. The paradox of self-stigma and mental illness. Clin. Psychol. Sci. Pract. 2002; 9: 35-53. 
13. Jarema M., Stygmatyzacja w obronie przed stygmatyzacją; konferencja Człowiek i rodzina a zdrowie psychiczne, Katowice 2016.

14. Cechnicki A., Wojciechowska A., Valdes M. Sieć społeczna a jakość życia osób chorujących na schizofrenię w siedem lat od pierwszej hospitalizacji. Psychiatr. Pol. 2007; 41(4): 527-537.

15. Cechnicki A, Wojciechowska A. Zależności pomiędzy właściwościami sieci społecznej a wynikami leczenia osób chorujących na schizofrenię $\mathrm{w}$ siedem lat od pierwszej hospitalizacji. Psychiatr. Pol. 2007; 41(4): 513-525.

16. Podogrodzka-Niell M., Tyszkowska, M. Stigmatization on the way to recovery in mental illness-the factors associated with social functioning. Psychiatr. Pol, 2014, 48(6), 1201-1211.

17. Crumlish N., Whitty P., Kamali M. i wsp. Early insight predicts depression and attempted suicide after 4 years in firstepisodeschizophrenia and schizophreniform disorder. Acta Psychiatr. Scand. 2005; 112: 449-455.

18. Cooke M., Peters E., Fannon D. i wsp. Insight, distress and coping styles in schizophrenia. Schizophrenia Research 2007; 94: 12-22.

19. Krupchanka, D., \& Katliar, M. (2016). The Role of Insight in Moderating the Association Between Depressive Symptoms in People With Schizophrenia and Stigma Among Their Nearest Relatives: A Pilot Study. Schizophrenia bulletin.

20. Mutsatsa S.H., Joyce E.M., Hutton S.B., Barnes T.R.E. Relationship between insight, cognitive function, social function and symptomatology in schizophrenia: The West London first episode study. Eur. Arch. Psychiatry Clin. Neuroscie. 2006; 256: 356-363.

21. Dequelson A., Saloppé X., Bandinelli A. Insight, Stigma et Autostigmatisation: l'intime conviction appliquée aux patients schizophrènes hospitalisés au sein d'un hôpital psychiatrique sécurisé. In Annales Médico-psychologiques, revue psychiatrique ; 2015, Vol.173, No. 10, pp. 913-915. Elsevier Masson.

22. Sawicka M., Charzyńska K. The role of a psychiatrist in treatment and recovery process of persons suffering from schizophrenia. Psychiatr. Pol, 2015, 49(2), 377-389.
23. Cannavò D., Minutolo G., Battaglia E., Aguglia E. Insight and recovery in schizophrenic patients. International journal of psychiatry in clinical practice, 2016, 20(2), 83-90.

24. Załuska M.: Funkcjonowanie społeczne i zapotrzebowanie na opiekę środowiskową $\mathrm{w}$ schizofrenii. Instytut Psychiatrii i Neurologii, Warszawa 2000.

25. Wilczek-Rużyczka E.,Halicka D. Wgląd w chorobę i poczucie wpływu na jej przebieg a funkcjonowanie społeczne pacjentów ze schizofrenią. Psychiatria i Psychologia Kliniczna,2013, 13(1).

26. Yıldırım A., Hacıhasanoğlu Așılar R., Camcıoğlu T. H., Erdiman S., Karaağaç E. Effect of Psychosocial Skills Training on Disease Symptoms, Insight, Internalized Stigmatization, and Social Functioning in Patients with Schizophrenia. Rehabilitation Nursing, 2015, 40(6), 341-348.

27. Hasson-Ohayon I., Kravetz S., Meir T., Rozencwaig S. Insight into severe mental illness, hope, and quality of life of persons with schizophrenia and schizoaffective disorders. Psychiatry Res. 2009; 167: 231-238.

28. Libman-Sokołowska M., Nasierowski, T. Rola nadziei w zmaganiach ze schizofrenią. Psychiatr. Pol, 2013, 47(5), 933-946.

29. Szaulińska K., Szafrański T. Medytacje nad treścią fantazmatu schizofrenii. W poszukiwaniu granic destygmatyzacji. Postępy Psychiatrii i Neurologii, 2015, 24(2), 45-51.

\section{Correspondence address:}

Ewelina Soroka

II Klinika Psychiatrii i Rehabilitacji Psychiatrycznej

Ul. Głuska 1, 20-439 Lublin

E-mail: dziwota.e@gmail.com

Otrzymano: 05.10.2016

Zrecenzowano: 28.10.2016, 21.11.2016

Przyjęto do druku: 04.12.2017 